\title{
Radioterapia hadronowa w Krakowie — przeszłość, teraźniejszość i przyszłość
}

\author{
Beata Sas-Korczyńska1, Tomasz Walasek², Bożena Romanowska-Dixon ${ }^{3}$
}

„... czas przemijający, doświadczenie złudne, wyrokowanie trudne...”

Hippokrates Aforyzmy

Panu Profesorowi Janowi Skołyszewskiemu, Mistrzowi sztuki leczenia chorych, pracy naukowej i interdyscyplinarnej współpracy, powyższą pracę dedykujq̨ wdzięczni uczniowie - autorzy

W obecnym opracowaniu omówiono w skrócie definicje i historię odkrycia niektórych hadronów (protonu i neutronu) oraz przesłanki i wskazania kliniczne do radioterapii hadronowej. Przedstawiono dotychczasowe doświadczenia krakowskiego ośrodka w stosowaniu radioterapii neutronowej (w latach 1978-1995) i radioterapii protonowej (stosowanej od 2011 roku) oraz perspektywy dalszego rozwoju.

\section{Hadron radiotherapy in Kraków - past, present and future}

The definition and discovery of some hadrons (protons and neutrons) and the rationale and clinical indications for hadron radiotherapy are presented in this paper. The authors describe the Kraków experience in the clinical use of neutron radiotherapy for the period 1978-1995 and the use of proton radiotherapy since 2011. The perspectives for progress for this method of radiotherapy is presented.

Słowa kluczowe: hadron, radioterapia neutronowa, radioterapia protonowa Key words: hadron, neutron radiotherapy, proton radiotherapy

NOWOTWORY Journal of Oncology 2014; 64, 3: 251-257

\section{Radioterapia hadronowa - definicja, historia, przesłanki i wskazania kliniczne}

W radioterapii hadronowej wykorzystywane są cząstki (tzw. hadrony), które charakteryzują silne oddziaływania, ładunek elektryczny oraz liczba barionowa. Obecnie fizyka cząstek elementarnych wyróżnia dwa rodzaje hadronów: bariony (zbudowane z 3 kwarków, posiadające połówkowy spin) oraz mezony (o spinie całkowitym, zbudowane z 2 kwarków).W radioterapii zastosowanie znalazły:z pierwszej grupy — nukleony, czyli protony i neutrony, a z drugiej - piony $\left(\pi^{-}\right)$.

\footnotetext{
${ }^{1}$ Klinika Onkologii

${ }^{2}$ Zakład Radioterapii

Centrum Onkologii — Instytut im. Marii Skłodowskiej-Curie

Oddział w Krakowie

${ }^{3}$ Klinika Okulistyki i Onkologii Okulistycznej

Szpital Uniwersytecki w Krakowie,

Katedra Okulistyki, Uniwersytet Jagielloński
} 
W dalszej części opracowanie koncentruje się przede wszystkim na aspektach związanych z radioterapią neutronową i protonową.

\section{Odkrycie nuklidów i powstanie radioterapii hadronowej}

W 1919 roku Ernest Rutherford odkrył istnienie protonu, a w 1932 roku James Chadwick odkrył neutron [1]. Dzięki możliwości przyspieszenia tych cząstek w cyklotronie już w 1938 roku w radioterapii zastosowano neutrony, jednak próby te zakończyły się niepowodzeniem. Ponownie podjęto je w latach 60. i 80. ubiegłego wieku, wówczas badania radiobiologiczne i kliniczne pozwoliły na ustalenie wskazań do radioterapii neutronowej. Niestety, nowoczesne techniki radioterapii oraz stosowanie radioterapii protonowej i jonowej spowodowały zaniechanie radioterapii neutronowej [2]. Obecnie jest ona prowadzona tylko w Cape Town w RPA [3].

Rozwój radioterapii protonowej przebiegał inaczej. W 1946 roku Robert R. Wilson zaproponował zastosowanie przyspieszonych protonów i jonów w radioterapii [4]. Uzasadnieniem tego były możliwość przyspieszenia protonów w cyklotronie oraz właściwości fizyczne wiązki protonowej (szczególnie charakterystyczny rozkład wielkości dawki na głębokości z tzw. pikiem Bragga). Zaledwie w 8 lat po propozycji R. R.Wilsona, w 1954 roku zespół Corneliusa A. Tobiasa przeprowadził radioterapię protonową u pierwszego pacjenta $[5,6]$. Według danych Particle Therapy Co-Operative Group (PTCOG) do końca 2012 roku radioterapię protonową przeprowadzono u 93895 chorych w różnych ośrodkach na świecie, w tym w Europie - u 31962 chorych. Obecnie radioterapia protonowa stosowana jest w 36 ośrodkach na świecie, w tym w 15 ośrodkach w Europie [7].

\section{Przesłanki do stosowania i wskazania kliniczne Radioterapia neutronowa}

Uzasadnieniem stosowania wiązki neutronowej w radioterapii są biologiczne skutki tego promieniowania, które wynikają z dużej wartości współczynnika liniowego przeniesienia energii (LPE). W porównaniu ze standardowym promieniowaniem skutki te $w$ mniejszym stopniu zależą od utlenowania eksponowanych tkanek, pozycji komórek w cyklu życiowym oraz mniej skuteczną naprawą subletalnych uszkodzeń popromiennych [8-10]. Ponadto $w$ radioterapii neutronowej obserwowana jest niewielka zależność biologicznego efektu od rodzaju napromienianej tkanki i od wielkości dawki frakcyjnej. Istotną rolę odgrywa tutaj wielkość dawki całkowitej, a nie sposób jej frakcjonowania [2].

Kliniczne wskazania do radioterapii neutronowej obejmowały przede wszystkim nowotwory o małej promieniowrażliwości: nowotwory ślinianek, nieoperacyjne przerzuty raka płaskonabłonkowego do węzłów chłonnych, miejscowo zaawansowany rak gruczołu krokowego, mięsaki tkanek miękkich oraz nieoperacyjne wznowy raka piersi po mastektomii [3, 10-16].

\section{Radioterapia protonowa}

Wiązka protonowa zawdzięcza swoje miejsce w radioterapii określonym cechom fizycznym, które prowadzą do charakterystycznego sposobu deponowania dawki w napromienianej materii. Skutki biologiczne obserwowane po zastosowaniu wiązki protonowej w zasadzie są takie same jak po użyciu wiązki fotonowej. Wartość współczynnika względnej skuteczności biologicznej (WSB) dla protonów wynosi 1,1-1,2 [17, 18].

Do charakterystycznych cech fizycznych wiązki protonowej należą: brak efektu narastania dawki w miejscu wejścia wiązki, homogennie niska dawka w początkowym przebiegu wiązki, nagły wzrost, a następnie nagły spadek dawki (tzw. pik Bragga) na określonej głębokości, praktycznie brak dawki na wyjściu wiązki oraz niewielkie rozproszenie boczne $[19,20]$. Cechy te umożliwiają precyzyjne podanie dawki do PTV (Planning Target Volume), przy jednoczesnym istotnym ograniczeniu dawki w obszarze zdrowych tkanek znajdujących się w sąsiedztwie nowotworu oraz na drodze przebiegu wiązki [17]. Zatem najważniejszym zyskiem ze stosowania radioterapii protonowej jest znakomita ochrona zdrowych tkanek i narządów krytycznych, co umożliwia bezpieczną eskalację dawki w obrębie PTV [21-23].

Kliniczne wskazania do radioterapii protonowej wynikają z fizycznych właściwości tej wiązki. Należą do nich nowotwory o małej promieniowrażliwości (wymagające podania dużej dawki) umiejscowione w obrębie albo w sąsiedztwie szczególnie wrażliwych narządów krytycznych [18, 19]. Klasyczne wskazania obejmują: czerniaka błony naczyniowej oka, struniaki i chrzęstniakomięsaki zlokalizowane w obrębie podstawy czaszki i w okolicy przykręgosłupowej oraz wybrane nowotwory u dzieci $[19,24]$. Prowadzone są również badania nad stosowaniem radioterapii protonowej w leczeniu chorych na inne nowotwory, między innymi: niedrobnokomórkowego raka płuca, raka gruczołu krokowego, oponiaków, raka przełyku, raka wątrobowokomórkowego, raka gardła środkowego oraz w napromienianiu części piersi (APBI - accelerated partial breast irradiation) z powodu raka piersi $[19,24]$.

\section{Radioterapia hadronowa w Krakowie}

\section{Radioterapia neutronowa w Krakowie (lata 1978-1995)}

Zastosowanie wiązki szybkich neutronów w radioterapii chorych na nowotwory złośliwe możliwe było dzięki współpracy Centrum Onkologii — Instytutu im. M. Skłodowskiej-Curie, Oddział w Krakowie i Instytutu Fizyki Jądrowej PAN im. H. Niewodniczańskiego.

Wiązka neutronów uzyskiwana była w klasycznym cyklotronie U-120 (ryc. 1), w którym deuterony, przyspieszone 

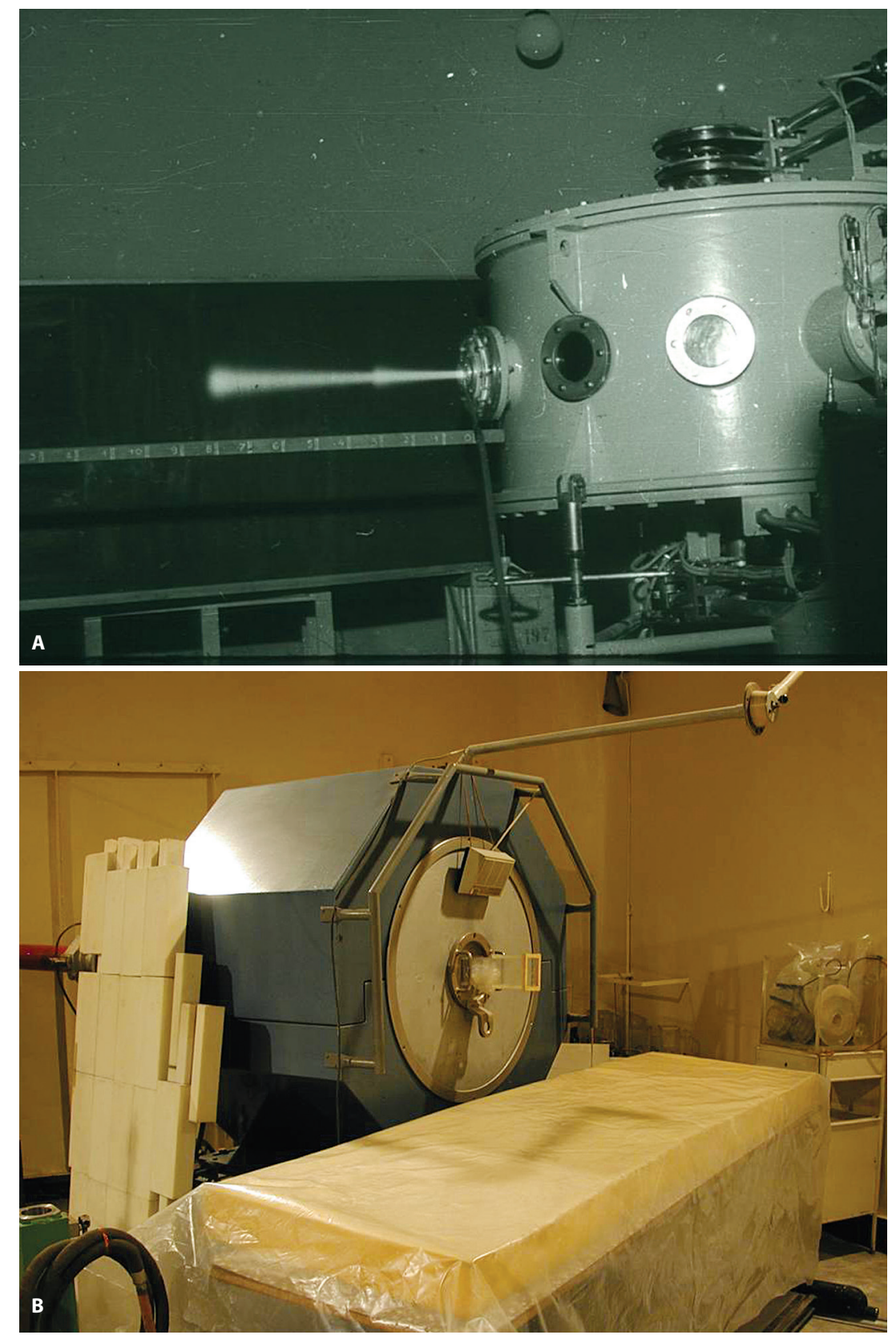

Rycina 1. Cyklotron U-122 (A) i stanowisko terapeutyczne (B) radioterapii neutronowej w latach 1978-1995

do maksymalnej energii 12,5 MeV, kierowane były na tarczę berylową. W wyniku reakcji ${ }^{9} \mathrm{Be}(\mathrm{d}, \mathrm{n})^{10} \mathrm{~B}$ powstawała wiązka neutronów. Jej średnia energia wynosiła 5,6 MeV, a średnia moc dawki $12 \mathrm{cGy}_{n, y}$ (jednostka ta oznaczała dawkę neutronową ze składową promieniowania gamma, która nie przekraczała $10 \%$ całej dawki). Parametry te wskazywały na ograniczenia możliwości stosowania wiązki neutronów do guzów zlokalizowanych nie głębiej niż 6-7 cm pod powierzchnią ciała [2, 25-30].

W okresie od 1978 do 1995 roku radioterapia neutronowa zastosowana była u 486 chorych. Najliczniejszą grupę stanowili chorzy na miejscowo zaawansowanego raka okolicy głowy i szyi. Stosowano różne schematy frakcjonowania daw- ki: 13,2 Gy $y_{n, y}$ w 20 frakcjach (okres: 1978-1986), 10-12 Gy ${ }_{n, y}$ w 10 frakcjach (okres: 1986-1988), 10-13 Gy ${ }_{n, \gamma}$ w 5 frakcjach (okres: 1988-1995). Najwyższe odsetki 3-letnich przeżyć bez objawów nowotworu obserwowano u chorych na zaawansowane, nieoperacyjne nowotwory złośliwe dużych gruczołów ślinowych, wykazujące wysoki stopień zróżnicowania histologicznego oraz u chorych z nieoperacyjnymi przerzutami do węzłów chłonnych wysoko zróżnicowanego raka z nieznanym lub wyleczonym ogniskiem pierwotnym. Odsetki te wynosiły odpowiednio $17 \%$ i 19\%. Uwzględniając zaawansowanie i rodzaj nowotworów, uzyskane wyniki wskazywały na skuteczność radioterapii neutronowej w takich sytuacjach klinicznych. Nie wykazano zależności wyników leczenia od sposobu 

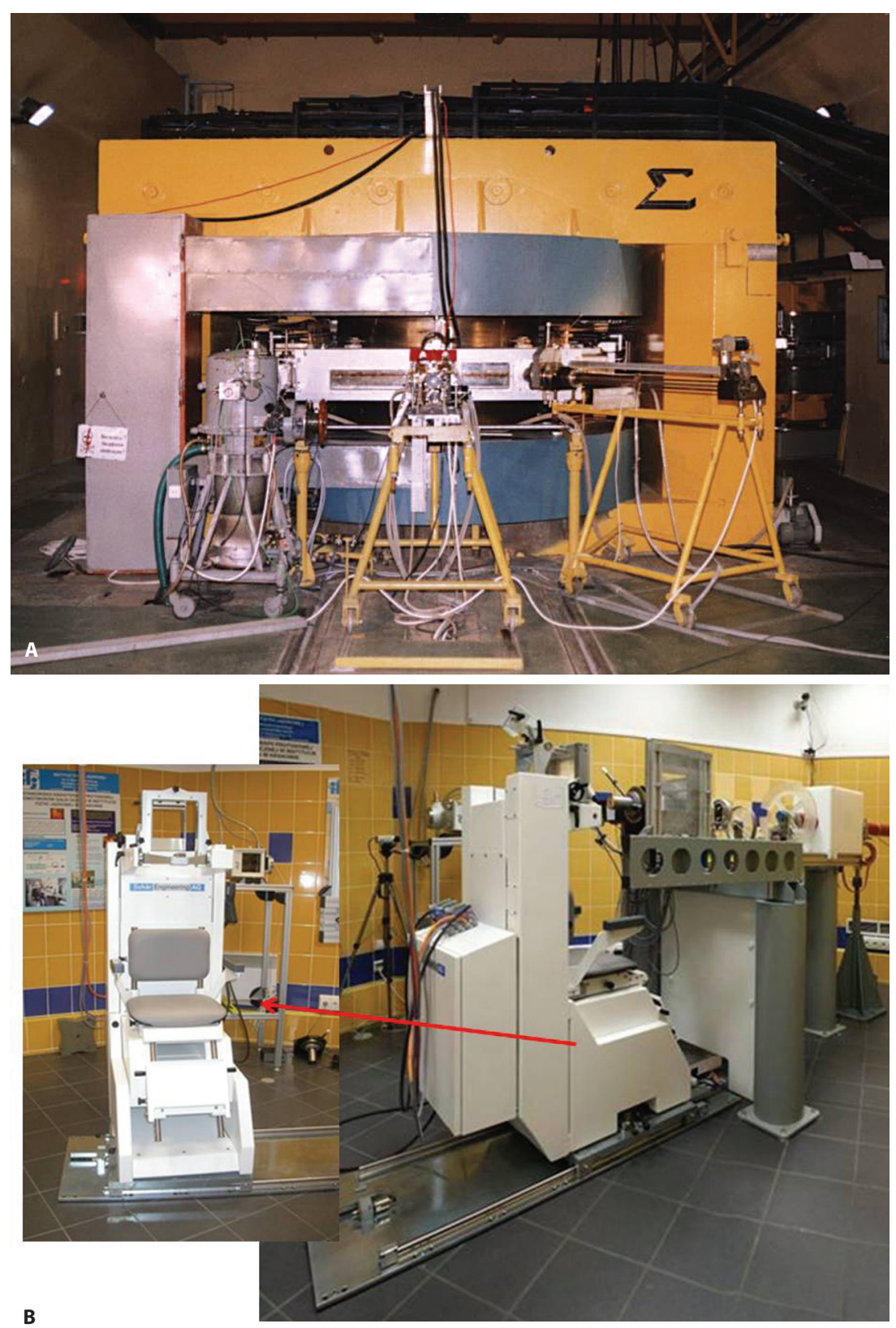

Rycina 2. Cyklotron AIC-144 (A) i stanowisko radioterapii protonowej (B) nowotworów narządu wzroku uruchomione w 2011 roku

frakcjonowania dawki [2], natomiast częstość powikłań była mniejsza w przypadku stosowania skróconych schematów frakcjonowania dawki $[2,31]$.

Radioterapia neutronowa stosowana była również w leczeniu nieoperacyjnych wznów raka piersi po mastektomii [32, 33]. W tym przypadku wykazano również skuteczność terapii neutronowej (całkowita remisja u 84\% chorych). Należy zwrócić uwagę, że u takich chorych ze względu na wysokie ryzyko rozwoju przerzutów odległych konieczne jest - poza leczeniem miejscowym — zastosowanie leczenia systemowego (chemioterapii, hormonoterapii).
Podsumowując krakowskie doświadczenia w stosowaniu radioterapii neutronowej, należy zauważyć, że metoda ta była skutecznym sposobem postępowania u chorych na nowotwory. Warunkiem tego było przestrzeganie wskazań i zapewnienie jakości leczenia, o których decyduje przede wszystkim interdyscyplinarna współpraca pomiędzy radioterapeutą, radiobiologiem i fizykiem. Ta interdyscyplinarna współpraca w krakowskim ośrodku, wypracowana podczas prowadzenia radioterapii neutronowej, została przeniesiona na inne obszary działalności kliniczno-naukowej. 

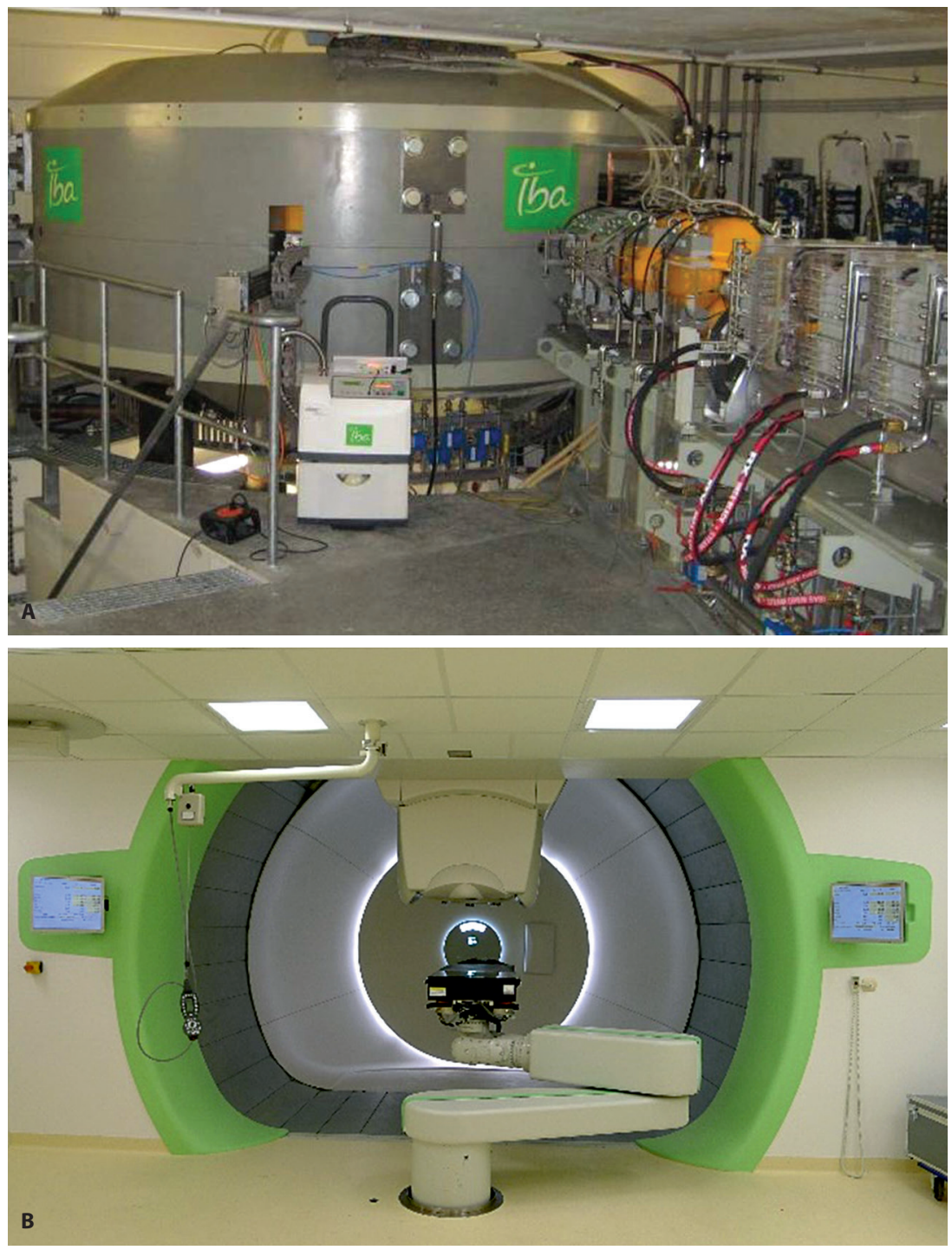

Rycina 3. Cyklotron Proteus-235 (A), który został zamontowany w 2012 roku i stanowisko terapeutyczne (B), które obecnie zostało zainstalowane

\section{Radioterapia protonowa w Krakowie (od 2011 roku)}

Dzięki współpracy Kliniki Okulistyki i Onkologii Okulistycznej Szpitala Uniwersyteckiego w Krakowie, Centrum Onkologii — Instytutu im. M. Skłodowskiej-Curie, Oddział w Krakowie i Instytutu Fizyki Jądrowej PAN im. H. Niewodniczańskiego w Krakowie w 2011 roku rozpoczęto stosowanie radioterapii protonowej u chorych na czerniaka błony naczyniowej oka.

Wiązka protonów uzyskiwana jest w izochronicznym cyklotronie AIC-144 (ryc. 2) znajdującym się w Instytucie Fizyki Jądrowej. Wiązka ta posiada energię $60 \mathrm{MeV}$, która umożliwia uzyskanie terapeutycznego zasięgu, wynoszącego $28,4 \mathrm{~mm}$. Ponadto charakteryzuje się bardzo wąskim obszarem półcienia (1,3 mm) oraz bardzo ostrym dystalnym spadkiem dawki. Wartość energii wiązki protonów, warun- kująca jej zasięg, ogranicza zastosowanie do radioterapii czerniaka błony naczyniowej oka. W celu uzyskania homogennego rozkładu dawki terapeutycznej wykorzystywana jest tutaj technika PSP (passive scattering protons), czyli biernego rozproszenia („poszerzenia”) piku Bragga [20].

Czerniak gałki ocznej jest rzadko występującym (ok. 1 przypadek na milion zachorowań), ale jednocześnie najczęstszym pierwotnym jej nowotworem i w $83 \%$ przypadków rozwija się w obrębie błony naczyniowej [34-36]. Zastosowanie radioterapii protonowej jest alternatywnym postępowaniem do wyłuszczenia gałki ocznej (enukleacji) w przypadku dużych guzów albo do brachyterapii w przypadku guzów zlokalizowanych w pobliżu plamki lub tarczy nerwu wzrokowego [37-41]. Radioterapia protonowa umożliwia miejscowe wyleczenie w $95 \%$, przy zachowaniu gałki ocznej u około $90 \%$ chorych i zachowaniu widzenia u połowy z nich [19, 24, 42-44]. 
Czerniak błony naczyniowej oka jest jednym z klasycznych wskazań do radioterapii protonowej. Według danych PTCOG metoda ta dotychczas, tj. od 1979 (początek stosowania) do końca 2012 roku, przeprowadzona została u 21970 chorych, co stanowi 23,4\% wszystkich leczonych wiązką protonową. Obecnie na świecie czynnych jest 13 ośrodków stosujących radioterapię protonową nowotworów oczu, z czego 9 w Europie [7].

W okresie od lutego 2011 do grudnia 2013 roku radioterapia protonowa zastosowana została u 39 chorych na czerniaka błony naczyniowej oka (do marca 2012 u 15 chorych w ramach terapii doświadczalnej, a od maja 2013 u 24 chorych w ramach kontraktu z NFZ). W czasie terapii podawana jest dawka 60 CGE (Cobalt Gray Equivalent, Kobaltowy Równoważnik Greja, 1 Gy odpowiada 1,1 CGE) w 4 frakcjach. Wstępne wyniki dotyczące grupy chorych leczonych do marca 2012 zostały opublikowane. Potwierdzają one skuteczność tej metody leczenia u chorych na czerniaka błony naczyniowej oka; regresję guza stwierdzono u 73\% chorych, a zachowanie gałki ocznej możliwe było u 93\% przypadków $[45,46]$.

Obecnie pacjenci z Kliniki Okulistyki i Onkologii Okulistycznej systematycznie poddawani są radioterapii protonowej z powodu czerniaka błony naczyniowej oka. W planowaniu i realizacji radioterapii uczestniczą lekarze z Centrum Onkologii w Krakowie oraz fizycy z Instytutu Fizyki Jądrowej w Krakowie. Jest to kontynuacja interdyscyplinarnej współpracy, zapoczątkowanej przez profesora Jana Skołyszewskiego podczas radioterapii neutronowej.

\section{Przyszłość radioterapii protonowej w Krakowie}

Na terenie Instytutu Fizyki Jądrowej PAN w Krakowie w marcu 2011 roku rozpoczęto budowę Centrum Cyklotronowego Bronowice (CCB). W maju 2012 roku zainstalowano izochroniczny cyklotron Proteus-235 (ryc. 3). Wiązka protonów uzyskiwana w tym cyklotronie posiada energię o zakresie 70-230 MeV, która umożliwia napromienienie nowotworów o różnej lokalizacji, położonych na różnej głębokości w stosunku do powierzchni ciała. Dodatkowym walorem tej wiązki jest możliwość stosowania technik skanujących (PBS - pencil-beam scanning) [20].

Obecnie trwa instalacja i adaptacja stanowiska terapeutycznego, a wiązka protonowa uzyskiwana z pracującego cyklotronu wykorzystywana jest już do badań doświadczalnych z zakresu fizyki jądrowej, radiobiologii i inżynierii materiałowej.

W przyszłości wiązka protonowa uzyskiwana w cyklotronie Proteus-235 znajdującym się na terenie CCB wykorzystywana będzie nie tyko w doświadczeniach naukowych, ale również w leczeniu chorych na nowotwory, które zapewni wielodyscyplinarna współpraca pomiędzy lekarzami, radiobiologami i fizykami.
Prof. nadzw. dr hab. med. Beata Sas-Korczyńska

Klinika Onkologii

Centrum Onkologii — Instytut im. Marii Skłodowskiej-Curie,

Oddział w Krakowie

ul. Garncarska 11,31-115 Kraków

e-mail:z5korczy@cyf-kr.edu.pl

Otrzymano i przyjęto do druku: 11 lutego 2014 r.

\section{Piśmiennictwo}

1. Suit HD, Chu W. History of charged particle radiotherapy. W: DeLaney TF, Kooy HM. Proton and charged particle radiotherapy. Philadelphia: Lippincott Williams\&Wilkins, 2008, s. 1-7.

2. Skołyszewski J. Radioterapia hadronowa i jonowa: osiągnięcia, perspektywy rozwoju. Nowotwory J Oncol 2007; 57: 370-375.

3. Stannard C, Vernimmen F, Carrara H i wsp. Malignant salivary gland tumours: can fast neutron therapy results point the way to carbon ion therapy? Radiother Oncol 2013; 109: 262-268.

4. Wilson RR Radiological use of fast protons Radiology 1946:47:487-491.

5. Tobias CA, Lawrence $\mathrm{JH}$, Born JL i wsp. Pituitary irradiation with high-energy proton beams: a preliminary report. Cancer Res 1958; 18 : 121-134.

6. Lawrence JH. Proton irradiation of the pituitary. Cancer 1957; 10 795-798.

7. www.ptcog.com

8. Fowler JF. Nuclear particles in cancer treatment. Bristol: Adam Hilger; 1981, 5-114.

9. Gasińska A. Biologiczne podstawy radioterapii. Ośrodek Edukacji Niestacjonarnej AGH, Kraków 2001: 15-20.

10. Skołyszewski J. Radioterapia neutronowa. Nowotwory 1993; 43 (supl. 1): $18-25$.

11. Skołyszewski J, Huczkowski J, Korzeniowski S. Radioterapia neutronowa nowotworów złośliwych w Krakowie. Stan obecny i perspektywy rozwoju. Nowotwory 1987; 37: 106-113.

12. Battermann JJ, Breur K. Results of fast neutron teletherapy for locally advanced head and neck tumors. Int J Radiat Oncol Biol Phys 1981; 7: 1045-1050.

13. Griffin TW, Davis R, Hendrickson FR i wsp. Fast neutron radiation therapy for unresectable squamous cell carcinomas of the head and neck: the results of randomized RTOG study. Int J Radiat Oncol Biol Phys 1984; 10: 2217-2221.

14. Catterall M. The treatment of malignant salivary gland tumors with fast neutrons. Int J Radiat Oncol Biol Phys 1981; 7: 1737-1738.

15. Duncan W, Orr JA, Arnott SJ i wsp. Neutron therapy for malignant tumours of the salivary glands. A report of the Edinburgh experience. Radiother Oncol 1987; 8: 79-104.

16. Duncan W, Arnott SJ, Orr JA i wsp. The Edinburgh experience of fast neutron therapy. Int J Radiat Oncol Biol Phys 1982; 8: 2155-2157.

17. Paganetti $H$, van Luijk P. Biological considerations when comparing proton therapy with photon therapy. Semin Radiat Oncol 2013; 23: 77-87.

18. Paganetti H, Niemierko A, Ancukiewicz M i wsp. Relative biologica effectiveness (RBE) values for proton beam therapy. Int J Radiat Oncol Biol Phys 2002; 53: 407-421.

19. Reinfuss M, Byrski E, WalasekT, Blecharz P. Postęp w technikach radioterapii i jego implikacje kliniczne. Nowotwory J Oncol 2011;61: 211-223.

20. Sas-Korczyńska B, Jakubowicz J. Radioterapia protonowa - dlaczego i kiedy? Med Prakt Onkol 2013; 4: 63-67.

21. Tubiana M. Can we reduce the incidence of second primary malignancies occurring after radiotherapy? A critical review. Radiother Oncol 2009; 91:4-15.

22. Hall EJ. Intensity-modulated radiation therapy, protons, and the risk of second cancers. Int J Radiat Oncol Biol Phys 2006; 65: 1-7.

23. Fogliata A, Bolsi A, Cozzi L. Critical appraisal of treatment techniques based on conventional photon beams, intensity modulated photon beams and proton beams for therapy of intact breast. Radiother Oncol 2002; 62: 137-145.

24. Egger E, Schalenbourg A, Zografos L i wsp. Maximizing local tumour control and survival after proton beam radiotherapy of uveal melanoma. Int J Radiat Oncol Biol Phys 2001: 51: 138-147.

25. Skołyszewski J, Huczkowski J, Byrski E i wsp. Kliniczne zastosowanie szybkich neutronów z cyklotronu U-120 w Krakowie. Nowotwory 1978; 29: 169-177.

26. Skołyszewski J, Byrski E, Chrzanowska A i wsp. A preliminary report on the clinical application of fast neutrons in Krakow. Int J Radiat Oncol Biol Phys 1982; 8: 1781-1786.

27. Skołyszewski J. First results of fast neutron therapy for advanced head and neck cancer in Krakow. Radiobiol Radiother 1982: 23: 15-19.

28. Skołyszewski J, Korzeniowski S, Huczkowski J. Results of fast neutron therapy in advanced head and neck cancer. Brit J Radiol 1988; 61: $301-304$ 
29. Skołyszewski J. Second report on fast neutron therapy of advanced head and neck cancer in Krakow. J Eur Radiother 1984; 5: 153-156.

30. Skołyszewski J, Reinfuss M. Results of fast neutron therapy for advanced carcinomas of the oral cavity and oropharynx. Radiobiol Radiother 1985; 26: 85-89.

31. Sas-Korczyńska B, Skołyszewski J. Ostre odczyny popromienne i późne powikłania po radioterapii neutronowej u chorych na zaawansowane nowotwory terenu głowy i szyi. Nowotwory 1996; 46: 698-706.

32. Skołyszewski J, Korzeniowski S, Huczkowski J. Terapia neutronowa miejscowej wznowy raka sutka po mastektomii. Nowotwory 1992; 42: 146-150.

33. Sas-Korczyńska B, Skołyszewski J. Radioterapia neutronowa nieoperacyjnych wznów raka piersi po masketktomii. Nowotwory J Oncol 2007; 57 (supl. 1): 20-21.

34. McLaaughlin CC, Wu XC, Jemal A i wsp. Incidence of noncutaneous melanomas in the U.S. Cancer 2005; 103: 1000-1007.

35. Isager P, Ehlers N, Overgaard J. Have choroidal and ciliary body melanomas changed during the period 1955-2000. Acta Ophthalmol Scand 2004; 82: 509-516.

36. Jovanovic $P$, Mihajlovic M, Djordjevic-Jocic J i wsp. Ocular melanoma: an overview of the current status. Int J Clin Exp Pathol 2013; 6: 1230-1244.

37. Egger E, Zografos L, Schalenbourg A i wsp. Eye retention after proton beam radiotherapy for uveal melanoma. Int J Radiat Oncol Biol Phys 2003; 55: 867-880.
38. Gragoudas ES, Goitein $M$, Koehler AM iwsp. Proton irradiation of small choroidal malignant melanomas. Am J Ophthalmol 1977; 83: 665-673.

39. Gragoudas ES, Goitein M, Verhey L i wsp. Proton beam irradiation. An alternative to enucleation for intraocular melanomas. Ophthalmology 1980; 87: 571-581.

40. Allen AM, Pawlicki T, Dong Li wsp. An evidence based review of proton beam therapy: the report of ASTRO's emerging committee. Radiother Oncol 2012; 103: 8-11.

41. Gragoudas ES, Munzenrider JE, Lane AM i wsp. Eye. W: DeLaneyTF, Kooy HM. Proton and charged particle radiotherapy. Philadelphia: Lippncott Williams\&Wilkins; 2008, 151-161.

42. Dendale R, Lumbroso Le R, Noel G i wsp. Proton beam radiotherapy fo uveal melanoma: results of Curie Institut-Orsay proton therapy center (ICPO). Int J Radiat Oncol Biol Phys 2006; 65: 780-787

43. Gragoudas ES, Marie Lane A. Uveal melanoma: proton beam irradiation Ophtalmol Clin North Am 2005; 18: 111-118, IX.

44. Munzenrider JE. Uveal melanonma. Concervation treatment. Hemato Oncol Clin North Am 2001; 15: 389-402.

45. Romanowska-Dixon B, Pogrzebielski A, Bogdali A i wsp. Radioterapia protonowa czerniaka błony naczyniowej - wstępne wyniki leczenia. Klinika Oczna 2012; 114: 173-179.

46. Sas-Korczyńska B, Markiewicz A, Romanowska-Dixon B, Pluta E. Preliminary results of proton radiotherapy for choroidal melanoma - the Krakow experience. Contemp Oncol 2014 (w druku).

W dniach 23-24 czerwca 2014 roku

Odbędzie się w Warszawie konferencja

Research-driven, multidisciplinary oncological care in Poland: sharing experiences to foster collaborations between MD Anderson Cancer Center Sister Institutions

Organizowana przez Instytut Hematologii i Transfuzjologii oraz Centrum Onkologii — Instytut im. Marii Skłodowskiej-Curie przy współpracy MD Anderson Cancer Center w Houston, USA

Celem konferencji jest przedstawienie przez amerykańskich i europejskich partnerów działających w sieci MD Anderson Cancer Center Sister Institutions zasad funkcjonowania reprezentowanych przez nich multidyscyplinarnych centrów onkologii. Szczególna uwaga będzie poświęcona ich miejscu w strukturze opieki nad chorymi na nowotwory, referencyjności oraz na znaczeniu badań naukowych.

Drugi dzień będzie miał charakter roboczy i dyskusyjny, z udziałem przedstawicieli

German Cancer Research Center (DKFZ, Heidelberg), Norway Radium Hospital (Oslo), Institute Gustave Roussy (Villejuif) oraz MD Anderson Cancer Center (Houston).

Miejsce: Courtyard by Mariott Warsaw Airport, ul. Żwirki i Wigury 1

Organizacja: VM Media sp. z o.o.

Program i inne informacje: www.research.viamedica.pl

Wstęp wolny. 